\title{
Sosialisasi Pemanfaatan Limbah Plastik Sebagai Bahan Pembuatan Paving Blok Untuk Menumbuhkan Jiwa Kewirausahaan Pada Mahasiswa
}

\author{
Ranty Christiana ${ }^{*}$, IkaMuthya Anggraini ${ }^{2}$, Hezliana Syahwanti ${ }^{3}$ \\ ${ }^{1,2,3}$ Universitas Panca Bhakti \\ Jl. Komodor Yos Sudarso, Kota Pontianak, Kalimantan Barat 78244 \\ *email: ranty_christiana@yahoo.co.id
}

\begin{abstract}
Abstrak
Banyak solusi yang telah dilakukan masyarakat untuk meminimalisir limbah plastik salah satunya adalah pembuatan kerajinan tangan dari limbah tersebut. Tetapi karena konsumsi masyarakat yang meningkat setiap tahunnya membuat limbah plastik juga tidak mengalami pengurangan. Sehingga dibutuhkan banyak solusi untuk memanfaatkan limbah plastik yang semakin meningkat jumlahnya setiap tahun. Salah satu pemanfaatannya adalah dengan menjadikan limbah plastik sebagai bahan pembuatan paving blok. Metode pembuatan paving blok yaitu dengan mencuci limbah plastik dan dikeringkan terlebih dahulu kemudian dilelehkan di dalam tungku, setelah semua limbah plastik meleleh kemudian dimasukkan ke dalam cetakan dan didiamkan selama kurang lebih 2 minggu. Hasil cetakan ini berupa paving blok yang ramah lingkungan. Cara tersebut kemudian disosialisasikan kepada masyarakat yang diwakili oleh mahasiswa Fakultas Teknik Universitas Panca Bhakti. Metode sosialisai yang digunakan ada 2 yaitu Metode Ceramah dan Metode Pendampingan (Workshop). Metode ceramah yaitu diskusi dan tanya jawab yang digunakan untuk menyampaikan informasi tentang pengolahan limbah menjadi paving blok. Metode Pendampingan yaitu bersifat konsultatif tentang pembuatan paving blok dari limbah plastik. Dengan adanya sosialisasi ini diharapkan dapat menambah pengetahuan serta membuka pikiran mahasiswa untuk memanfaatkan limbah menjadi bahan dengan nilai jual dan nilai guna yang lebih tinggi. Paving blok yang berbahan dasar limbah plastik dapat dijadikan salah satu produk untuk wirausaha. Jiwa kewirausahaan harus dibentuk sejak dini untuk menumbuhkan rasa kemandirian pada kalangan remaja khususnya mahasiswa yang memiliki kemampuan yang lebih besar untuk menciptakan ide dan inovasi dengan berbagai sumber di era digital 4.0 dapat memanfaatkan paving blok yang ramah lingkungan sebagai produk bernilai jual lebih tinggi.
\end{abstract}

Kata Kunci: Sosialisasi, Limbah Plastik, Paving Blok

\section{Pendahuluan}

Penggunaan kantong plastik oleh masyarakat merupakan penyumpang sampah plastik terbesar. Lebih dari 100 miliar kantong plastik yang digunakan per tahunnya. Sehingga sering dilakukan kegiatan untuk menanggulangi masalah sampah plastik tersebut. Salah satunya 
ISSN : $2620-4665$ (print)

ISSN : $2620-4673$ (online)

Website : http://jurnal.untan.ac.id/index.php/JPLP2KM

adalah dengan pemilihan sampah dan pewadahan. Pemilihan sampah merupakan kegiatan mengelompokkan dan memisahkan sampah sesuai dengan jenisnya. Sedangkan pewadahan adalah kegiatan menampung sampah sementara dalam suatu wadah baik individual maupun komunal di tempat sumber sampah dengan mempertimbangkan jenis dari sampah tersebut.

Sejauh ini keterlibatan masyarakat dalam mengurangi pemakaian dan mendaur ulang plastik masih sangat minim. Biasanya plastik dibakar untuk memusnahkannya dari pandangan. Padahal, jika pembakaran plastik tidak sempurna (di bawah $800^{\circ} \mathrm{C}$ ) dapat membentuk dioksin, yaitu senyawa yang dapat memicu kanker, hepatitis, pembengkakan hati dan gangguan system saraf (Sirait, 2009).

Pencemaraan lingkungan akibat limbah plastik dapat dikurangi dengan mengolah limbah tersebut menjadi bahan yang lebih berguna dan bernilai jual lebih tinggi. Salah satunya dengan memanfaatkan limbah plastik sebagai bahan pembuatan paving blok (Burhanuddin dan MRS Darmanijati, 2018). Pembuatan paving blok berbahan limbah plastik tidak sulit untuk dilakukan sehingga dapat menjadi salah satu ide wirausaha bagi kalangan remaja.

Mahasiswa yang merupakan kalangan milenial menjadi dasar awal dalam perkembangan ilmu pengetahuan dan teknologi. Saat ini banyak mahasiswa yang mengembangkan ilmu mereka saat masih duduk dibangku kuliah. Tetapi saat lulus kuliah mereka berasumsi bahwa bekerja di perusahaan atau menjadi pegawai adalah hal yang lebih dihargai dikalangan masyarakat. Sehingga banyak dari mereka tidak mengembangkan ide setelah lulus kuliah.

Pemikiran tersebut harus diubah sejak awal, karena mahasiswa sebagai kalangan milenial merupakan agen perubahan bangsa. Mereka harus dibina untuk memiliki pola pikir dan jiwa berwirausaha. Banyak hal yang dapat dilakukan oleh kalangan milenial untuk memulai usaha bahkan dengan memanfaatkan barang yang tidak terpakai atau limbah.

Limbah plastik atau sampah plastik yang menjadi permasalahan bangsa setiap tahunnya dapat menjadi peluang usaha yang dapat dikembangkan oleh mahasiswa. Limbah plastik tersebut dapat menjadi bahan dasar pembuatan paving blok sehingga dapat mengurangi pencemaran lingkungan akibat pembuangan limbah plastik. Paving blok tersebut dapat dimanfaatkan dalam dunia konstruksi ataupun bangunan. Sehingga limbah plastik dapat menjadi barang yang memiliki nilai guna dan manfaat yang lebih tinggi. Pembuatan paving blok berbahan dasar limbah plastik dapat menjadi salah satu ide wirausaha yang dapat dikembangkan oleh mahasiswa. Kegiatan Pengabdian Kepada Masyarakat (PKM) menjadi salah satu cara penyampaian ide kepada mahasiswa sebagai kalangan milenial sehingga mereka memiliki motivasi untuk berwirausaha.

Tujuan dari PKM Program Kemitraan Masyarakat kali ini adalah untuk memberikan wawasan serta motivasi wirausaha kepada kalangan milenial khususnya mahasiswa Fakultas Teknik Universitas Panca Bhakti dalam penggunaan limbah plastik dan botol plastik menjadi paving blok. Tujuan jangka panjang dari program ini adalah kemandirian mahasiswa dalam 
bidang ekonomi dengan memanfaatkan bahan tak terpakai atau limbah menjadi suatu produk yang berdaya jual tinggi.

\section{Metode}

Berdasarkan permasalahan yang telah diuraikan sebelumnya maka solusi permasalah yang telah dilaksanakan di lokasi kegiatan adalah dengan memberikan sosialisasi terhadap mahasiswa Fakultas Teknik Universitas Panca Bhakti Pontianak dengan judul "Pemanfaatan Limbah Plastik Sebagai Bahan Dasar Pembuatan Paving Blok Untuk Menumbuhkan Jiwa Kewirausahaan Pada Kalangan Milenial Di Era Digital 4.0".

Sosialisasi dilakukan untuk memberikan gambaran kepada mahasiswa sebagai kalangan milenial bahwa ada solusi untuk menangani masalah pencemaran lingkungan dengan memanfaatkan ilmu pengetahuan dan teknologi yang mereka miliki dalam membuat suatu produk yang memiliki nilai guna dan nilai jual yang lebih tinggi. Permasalahan lingkungan yang diatasi adalah dengan memanfaatkan sampah plastik atau limbah plastik menjadi bahan dasar pembuatan paving blok.

Setelah selesai menerima materi dalam sosialisasi kemudian mahasiswa diarahkan untuk melihat proses pembuatan paving blok dengan bahan dasar limbah plastik. Praktek pembuatan dilakukan dengan melihat alat dan barang apa saja yang dibutuhkan dan melihat proses pembuatannya. Setelah itu melihat produk hasilnya berupa paving blok yang berbahan dasar limbah plastik.

PKM ini dilakukan agar mahasiswa memiliki pandangan bahwa untuk memulai berwirausaha tidak selalu dengan modal dan bahan yang besar. Mereka dapat memanfaatkan barang disekitar mereka dan dapat menghasilkan barang yang memiliki nilai guna dann nilai jual yang lebih tinggi dengan proses yang tidak sulit. Sehingga diharapkan dapat menumbuhkan jiwa kewirausahaan dalam diri mereka.

Pengabdian Kepada Masyarakat (PKM) Program Kemitraan Masyarakat yang dilaksanakan di Universitas Panca Bhakti (UPB) Pontianak bekerjasama dengan Fakultas Teknik UPB Pontianak. Mahasiswa Fakultas Teknik berjumlah 50 orang sebagai peserta dalam kegiatan ini. Metode yang digunakan dalam kegiatan PKM Program Kemitraan Masyarakat kali ini ada 2 yaitu:

a. Metode ceramah, diskusi, dan tanya jawab digunakan untuk menyampaikan informasi tentang ide wirausaha dengan pengolahan limbah menjadi paving blok. 
ISSN : $2620-4665$ (print)

ISSN : $2620-4673$ (online)

Website : http://jurnal.untan.ac.id/index.php/JPLP2KM

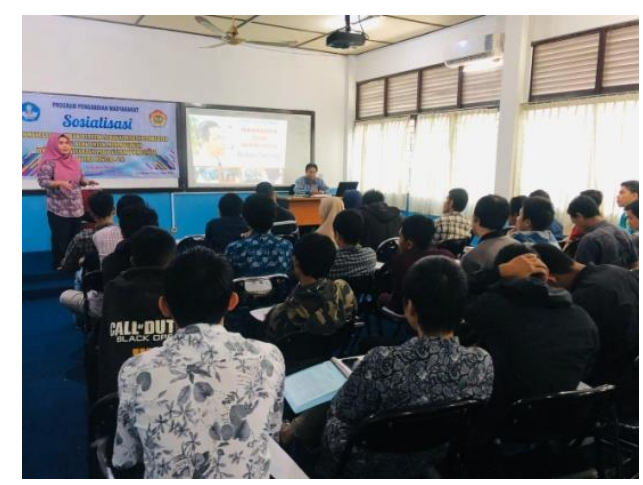

Gambar 1. Sosialisasi

b. Metode pendampingan/workshop yang sifatnya konsultatif tentang pembuatan paving blok dari limbah plastik.

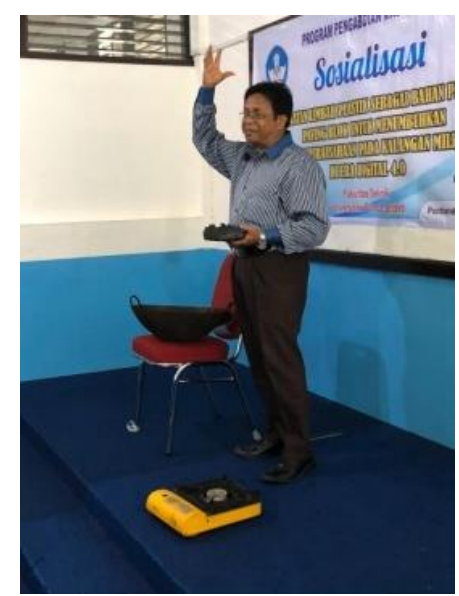

Gambar 2. Workshop/Pendapingan

\section{Hasil dan Pembahasan}

Berdasarkan permasalahan yang telah diuraikan sebelumnya maka solusi permasalah yang telah dilaksanakan di lokasi kegiatan adalah dengan memberikan sosialisasi terhadap mahasiswa Fakultas Teknik Universitas Panca Bhakti Pontianak dengan judul "Pemanfaatan Limbah Plastik Sebagai Bahan Dasar Pembuatan Paving Blok Untuk Menumbuhkan Jiwa Kewirausahaan Pada Kalangan Mahasiswa".

Sosialisasi dilakukan untuk memberikan gambaran kepada mahasiswa sebagai kalangan milenial bahwa ada solusi untuk menangani masalah pencemaran lingkungan dengan memanfaatkan ilmu pengetahuan dan teknologi yang mereka miliki dalam membuat suatu produk yang memiliki nilai guna dan nilai jual yang lebih tinggi. Permasalahan lingkungan yang diatasi adalah dengan memanfaatkan sampah plastik atau limbah plastik menjadi bahan dasar pembuatan paving blok.

Setelah selesai menerima materi dalam sosialisasi kemudian mahasiswa diarahkan untuk melihat proses pembuatan paving blok dengan bahan dasar limbah plastik. Praktek 
pembuatan dilakukan dengan melihat alat dan barang apa saja yang dibutuhkan dan melihat proses pembuatannya. Setelah itu melihat produk hasilnya berupa paving blok yang berbahan dasar limbah plastik.

PKM ini dilakukan agar mahasiswa memiliki pandangan bahwa untuk memulai berwirausaha tidak selalu dengan modal dan bahan yang besar. Mereka dapat memanfaatkan barang disekitar mereka dan dapat menghasilkan barang yang memiliki nilai guna dann nilai jual yang lebih tinggi dengan proses yang tidak sulit. Sehingga diharapkan dapat menumbuhkan jiwa kewirausahaan dalam diri mereka.

Berdasarkan permasalahan yang telah diuraikan sebelumnya maka pelaksana berpendapat bahwa perlu adanya sosialisai dari pemateri yang memiliki kepakaran dalam bidang wirausaha. Selain itu juga terdapat contoh produk yang dapat dibuat dan dihasilkan sebagai salah satu ide untuk berwirausaha. Sosialisasi yang telah dilaksanakan dihadiri oleh narasumber yang bernama Hatta Siswa Mahyaya, S.Hut dengan materi Membangun Jiwa Wirausaha Pada Kalangan Milenial Pada Era Digital 4.0.

Sosialisasi ini bertujuan untuk memberikan pandangan kepada mahasiswa sebagai alangan milenial bahwa mereka tidak selalu harus menjadi pegawai untuk memiliki penghasilan, tetapi dapat juga dengan memulai berwirausaha. Jiwa kewirausahaan harus ditumbuhkan sejak dini agar dapat mengatur pola pikir kalangan milenial dan memotivasi mereka untuk memulai berpikir dan mencari solusi dalam berwirausaha. Pemberian contoh produk yang murah dan mudah dilakukan untuk memulai wirausaha dilakukan saat sosialisasi agar mereka mendapat pandangan pembuatan produk tidaklah sulit. Salah satu contoh produk yang diambil adalah pembuatan paving blok berbahan dasar limbah plastik.

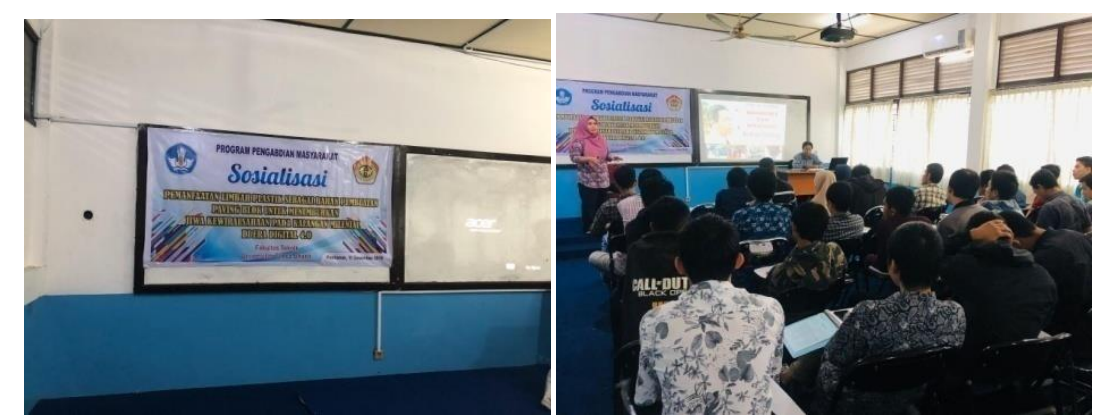

Gambar 3. Sosialisasi di FT UPB

Pembuatan paving blok berbahan dasar limbah plastik juga dilakukan untuk memberikan pengetahuan tambahan kepada mahasiswa bahwa terdapat produk yang gampang dan mudah diproduksi dalam dunia teknik sipil. Setiap alat dan proses pembuatan diperlihatkan kepada mahasiswa sampai pada hasil akhir yaitu paving blok. Antusias dan semangat dari mahasiswa dalam mengikuti sosialisasi dan workhsop ini dapat terlihat dari sesi tanya jawab mereka. Sehingga mereka memiliki kemauan dan pandangan ke depannya bahwa masih ada produk yang dapat mereka buat dengan mudah dan bahan produksi yang gampang ditemukan. Serta dapat menjadi solusi untuk masalah pencemaran lingkungan. 
ISSN : $2620-4665$ (print)

ISSN : $2620-4673$ (online)

Website : http://jurnal.untan.ac.id/index.php/JPLP2KM

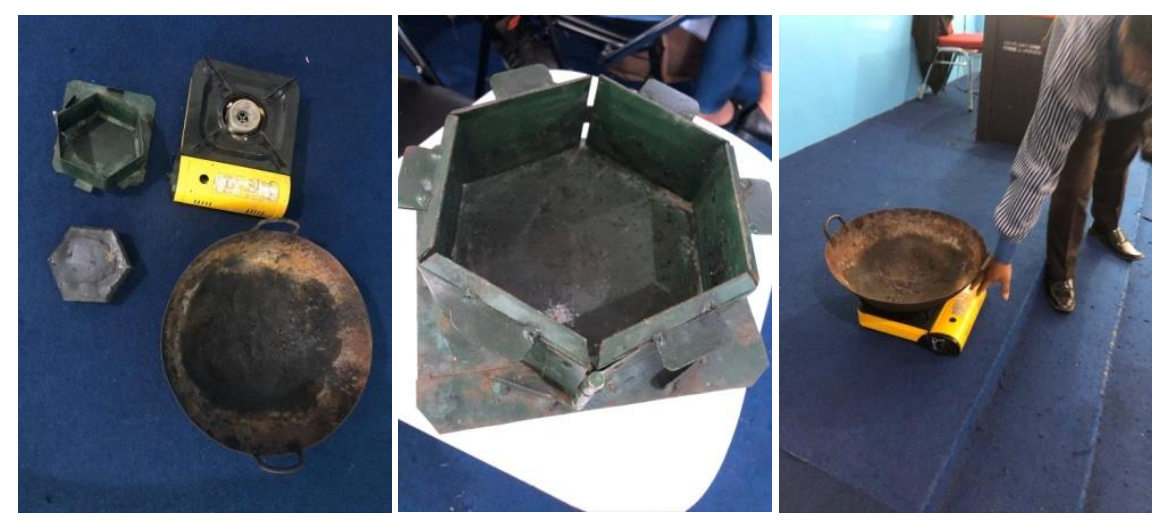

Gambar 5. Workshop Pembuatan Paving Blok

\section{Kesimpulan dan Rekomendasi}

\section{a. Simpulan}

Sosialisasi yang dilakukan bertujuan untuk mengenalkan produk yang dapat diolah dengan mudah dan berasal dari limbah yang tak terpakai. Produk yang dipilih yaitu paving blok. Pembuatan paving blok dengan limbah plastik dapat menjadi salah satu cara dalam meminimalisir keberadaan limbah plastik yang meningkat setiap tahunnya. Sosialisasi dilakukan di kalangam mahasiswa dengan tujuan untuk memberikan pandangan kepada mahasiswa bahwa banyak potensi bahan dan cara mudah yang dapat mereka lakukan untuk menghasilkan suatu produk dengan nilai jual tertentu. Selain sosialisasi, mahasiswa juga di dampingi dalam pembuatan paving blok. Ini dilakukan agar mahasiswa dapat secara langsung belajar dan praktek untuk pembuatan paving blok tersebut.

\section{b. Rekomendasi}

Diharapkan kedepannya mahasiswa dapat menjadikan paving blok sebagai salah satu produk usaha rumahan dan mendapat koneksi dalam pemasaran paving blok tersebut.

\section{Ucapan Terima Kasih}

Terima kasih kepada Lembaga Penelitian dan Pengabdian Kepada Masyarakat Universitas Panca Bhakti untuk dukungan moral dan dana sebagai mitra dalam kegiatan PKM ini. Terima kasih juga diberikan kepada Fakuktas Teknik Universitas Panca Bhakti yang telah menyediakan waktu dan tempat dalam pelaksanaan program ini.

\section{Daftar Pustaka}

Burhanuddin B. dan MRS Darmanijati. 2018. Pemanfaatan Limbah Plastik Bekas Untuk Bahan Utama Pembuatan Paving Block. Jurnal Rekayasa Lingkungan Vol. 18/No.1/April 2018.

Deloitte Indonesia Prespective. 2019. Generasi Milenial Dalam Industri 4.0: Berkah Bagi Sumber Daya Manusia Indonesia Atau Ancaman. 
Pambudi Sunarsihanto. 2019. dalam Deloitte Indonesia Prespective. Generasi Milenial Dalam Industri 4.0: Berkah Bagi Sumber Daya Manusia Indonesia Atau Ancaman.

Putra, H, P., \& Y, Yuriandala. 2010. Studi Pemanfaatan Sampah Plastik Menjadi Produk dan Jasa Kreatif. Jurnal Sains dan Teknologi Lingkungan 2 (1), 21-31.

Sirait, M. 2009. Sulap Sampah Plastik Lunak jadi Jutaan Rupiah. B -Frist. Yogyakarta

Sofiana, Y. 2010. Pemanfaatan Limbah Plastik Sebagai Alternatif Bahan Pelapis (Upholstery) Pada Produk Interior. Jurnal Humaniora 1 (2), 331-337.

Wahyudi, E., Zultiniar, \& E, Saputra. 2016. Pengolahan Sampah Plastik Polipropilena (PP) Menjadi Bahan Bakar Minyak dengan Metode Perengkahan Katalitik Menggunakan Katalis Sintetis. Jurnal Rekayasa Kimia dan Lingkungan 11 (1), 17-23. 